\title{
The Development of Blended Learning Model Using Wordpress
}

\author{
Muhammad Hifzi Adini, Harja Santana Purba, R. Ati Sukmawati \\ Departement of Computer Science Education, \\ Universitas Lambung Mangkurat \\ hifdzi.adini@gmail.com
}

\begin{abstract}
In general, the learning process is implemented using face-to-face model, meaning that students and teachers are in one place and at one time. With this model, common communication between students and teachers can be easily implemented. However, there are some obstacles that may be faced such as the lack of time to discuss and the limited space that can be used. To overcome these problems, a model that provides a medium for gathering students and teachers without limited time and space is needed. One of these models is known as blended learning. The blended learning model allows students and teachers to discuss and share material as well as practice questions on a virtual classroom. The research undertaken was to develop a blended learning model using an analysis of the blended learning implementation framework and the use of Content Management System (CMS) WordPress technology. This model is expected to be an additional medium used to support the teaching and learning processes.
\end{abstract}

Keywords—Blended learning;Virtual class; Wordpress.

\section{INTRODUCTION}

The development of a blended learning model is a combination of face-to-face conventional classroom teaching and online virtual classroom. The use of blended learning model aims to unlimit the time and space in conventional class. The blended learning model should be implemented using a good framework for optimum results. In addition to a good framework, the selection of appropriate supporting technologies can also be a successful factor in the application of blended learning.

The research is conducted to analyze the application framework of blended learning model and analysis of technology selection supporting model. The framework used refers to the existing research results while the technology used was the CMS WordPress. This CMS was chosen because in addition to open licensed, it also has a number of features that are quite complete and the number of plugins developed. Given a good framework and appropriate technology, the development of blended learning model is expected to run properly.

\section{LITERATURE REVIEW}

\section{A. Blended Learning}

Blended learning is a combination of conventional learning model in the classroom and an online learning model. This model allows students and teachers to interact in unlimited time and space. Blended learning combines aspects of web/ internet based learning, video streaming, as well as synchronous and asynchronous audio communications with traditional "face to face" learning [1].

The use of blended learning model has been increasing and adopted by many schools, colleges, universities and industries around the world [2]. Blended learning will be a tool that encourages the proportion of teaching in secondary schools offered in online form by $50 \%$ by 2019 [3].

The online learning model has a number of advantages, including[4], [5]: (1) increasing time for students to repeat the lessons; (2) helping introvert students to learn without embarrassment; (3) allowing each individual to study independently; (4) allowing individuals to follow learning in their own more comfortable environment; and (5) learning materials can be easily reproduced and distributed for all students.

The blended learning model can be implemented using a number of approaches. There is an identification of approaches that can be used to develop blended learning model in higher education such as supplemental, replacements, emporiums, fully online, and buffets. More details can be seen in Table I.

Implementation of blended learning itself needs to be well planned in order to run well and provide optimum results. In general, the application of blended learning system consists of eight stages, namely [5]: (1) defining the learning objectives; (2) analyzing the students learning; (3) establishing readiness; (4) determining pedagogical approaches and instructional strategies; (5) developing blended learning model; (6) implementing of blended learning model; (7) collecting feedback for evaluation; and (8) finishing the final form of the system. 
TABLE I. BLENDED LEARNING MODEL IN HIGHER EDUCATION[6]

\begin{tabular}{|c|c|}
\hline Approaches & $\begin{array}{l}\text { Description } \\
\end{array}$ \\
\hline Supplemental & $\begin{array}{l}\text { (1) Maintaining the basic structure of traditional } \\
\text { teaching, especially the number of face-to- } \\
\text { face meetings. } \\
\text { (2) Adding lectures and books with a number of } \\
\text { online activities (example: online quiz). }\end{array}$ \\
\hline Replacements & $\begin{array}{l}\text { (1) Reducing meeting time in class. } \\
\text { (2) Changing face-to-face meetings with online } \\
\text { learning activities for students. }\end{array}$ \\
\hline Emporium & $\begin{array}{l}\text { (1) Eliminating all classroom meetings. } \\
\text { (2) Replacing all classroom meetings with } \\
\text { centralized learning that provides materials } \\
\text { online. } \\
\text { (3) Allowing students to learn independently as } \\
\text { needed. }\end{array}$ \\
\hline Fully Online & $\begin{array}{l}\text { (1) All learning activities are done online } \\
\text { (2) Using automated assessment system to } \\
\text { provide fast feedback to students. }\end{array}$ \\
\hline Buffet & $\begin{array}{l}\text { Offering students a range of learning offer options } \\
\text { such as teaching materials, group reviews, group } \\
\text { study sessions, and videos. }\end{array}$ \\
\hline
\end{tabular}

In addition to consider the approach to be used, the application of blended learning model requires attention to a number of issues that can be considered. The detail can be seen in Table II.

\section{TABLE II. ISSUES RELATED TO THE IMPLEMENTATION OF BLENDED LEARNING MODEL [2], [5],[6]}

\begin{tabular}{|c|l|}
\hline Keywords & \multicolumn{1}{|c|}{ Consideration } \\
\hline Institutional support & (1) Is there any sufficient technical \\
support?
\end{tabular}

\section{B. WordPress}

WordPress is a Content Management System (CMS) technology that can be used to build web, personal blog, or Learning Management System (LMS). One of the main advantages of the WordPress is the amount of plug in that was developed by independent developers [7].
WordPress is one of the CMS licensed open. It can be used for free. Based on a survey conducted by Alexa, WordPress received a percentage of $12.5 \%$ for one million websites using CMS technology, followed by Joomla $2.5 \%$ and Drupal at a percentage of $1.4 \%$ [8]. The key features owned by WordPress among others are (1) dashboard for content setting; (2) writing management (post); (3) media management (images, audio, video); (4) page creation; (5) comment management comments; (6) setting themes, views, menus, and headers; (7) plug in management; and (8) user management

\section{ANALYSIS}

\section{A. The Blended Learning Implementation Framework}

Application of the blended learning model should be done in a planned manner. Research that has been done by experts can be used as a reference for the application framework of blended learning such as research conducted by Hew and Cheung [2] as summarized in Table III.

\section{TABEL III. BLENDED LEARNING FRAMEWORK [2]}

\begin{tabular}{|c|c|}
\hline $\begin{array}{c}\text { Step } \\
\end{array}$ & $\begin{array}{l}\text { Description } \\
\end{array}$ \\
\hline 1. Determining learning goals & $\begin{array}{l}\text { This stage is done to determine the } \\
\text { expected objectives of the } \\
\text { development of blended learning } \\
\text { system. In addition, the purpose can } \\
\text { be used as a control to perform } \\
\text { monitoring and evaluation of system } \\
\text { implementation. }\end{array}$ \\
\hline 2. Analyzing students learning & $\begin{array}{l}\text { This stage is done to analyze the } \\
\text { students readiness. In detail, this } \\
\text { stage is in step } 3 \text { (this stage can be } \\
\text { ignored). }\end{array}$ \\
\hline 3. Establishing readiness & $\begin{array}{l}\text { At this stage, there are five main } \\
\text { issues to be considered: (1) } \\
\text { institutional support; } \\
\text { infrastructural readiness; (3) content } \\
\text { readiness; (4) instructor readiness; } \\
\text { (5) learner readiness }\end{array}$ \\
\hline $\begin{array}{l}\text { 4. Determining pedagogical } \\
\text { approach and instructional } \\
\text { strategy }\end{array}$ & $\begin{array}{l}\text { At this stage, pedagogical approach } \\
\text { in system development is determined. }\end{array}$ \\
\hline $\begin{array}{l}\text { 5. Developing blended learning } \\
\text { model }\end{array}$ & $\begin{array}{l}\text { At this stage, the development of } \\
\text { blended learning model is desired. } \\
\text { There are five forms of model that } \\
\text { can be used as a reference: (1) } \\
\text { supplemental; (2) replacements; (3 } \\
\text { emporium; (4) fully online; and (5) } \\
\text { buffet. }\end{array}$ \\
\hline $\begin{array}{l}\text { 6. Implementing blended learning } \\
\text { model }\end{array}$ & $\begin{array}{l}\text { This stage is executed to perform the } \\
\text { implementation of the previous steps. } \\
\text { The selection of technology will be } \\
\text { used to develop blended learning } \\
\text { system. }\end{array}$ \\
\hline $\begin{array}{l}\text { 7. Collecting feedback for } \\
\text { evaluation }\end{array}$ & $\begin{array}{l}\text { This stage is run to evaluate and } \\
\text { monitor the system that has been } \\
\text { implemented; the objectives } \\
\text { contained in step } 1 \text { can be used as } \\
\text { evaluation reference. }\end{array}$ \\
\hline 8. The final form of the system & $\begin{array}{l}\text { Once the system is applied and } \\
\text { evaluated, it is expected to form a } \\
\text { blended learning system that fits the } \\
\text { purpose. }\end{array}$ \\
\hline
\end{tabular}


Based on the results of the analysis on the application framework of the blended learning system, the simplification of the steps that can be used for the application of blended learning can be seen in Fig. 1 adopted from [2]).

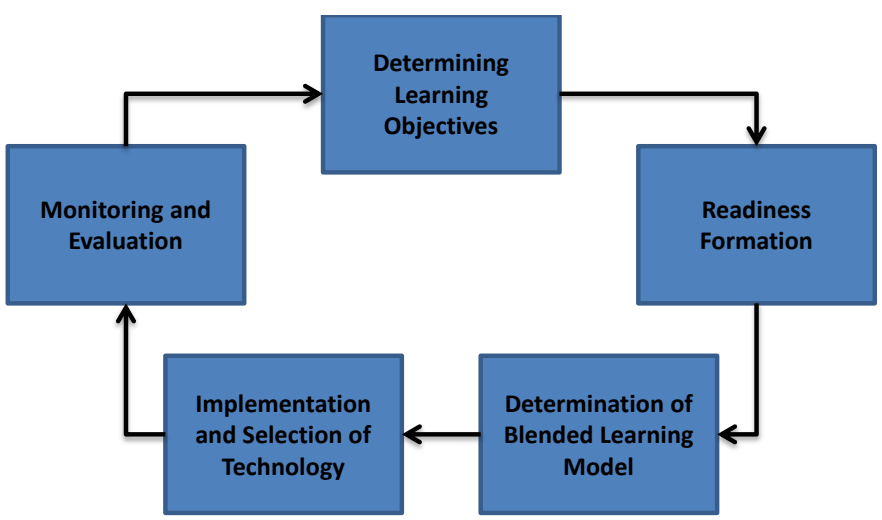

Fig 1. The Blended Learning Implementation Framework

\section{B. WordPress as Supporting Technology}

The use of blended learning model is the mixing of conventional learning model (face-to-face) in class with internet-based learning model. The technology used to support blended learning model must be able to represent the real conditions contained in the physical class.

WordPress is one CMS that can be developed as a supporting technology in blended learning model. Mapping WordPress features with attributes found in physical classes can be used as a reference for WordPress selection as a support technology (Table IV).

TABLE IV. MAPPING OF CONVENTIONAL CLASSROOM AND WORDPRESS ATTRIBUTES

\begin{tabular}{|c|c|}
\hline Conventional Class & WordPress \\
\hline The teacher gives an explanation & Audio Media \\
& Video Media \\
& Post \\
\hline Teaching materials & Audio Media \\
& Video Media \\
& Post \\
\hline Class Discussion & Comment \\
\hline Assignment & Audio Media \\
& Video Media \\
\hline Collecting of Assignment & Post \\
\hline & Email \\
\hline
\end{tabular}

\section{RESULTS}

Based on the results of the framework analysis, the stages in the development of blended learning system consists of five steps, namely determining learning objectives, establishing the formation of readiness, determining blended learning model, implementing the technology selection, as well as monitoring and evaluating.

The focus of this research is on the implementation and selection of technology. Development of the blended learning model can be done by using WordPress. WordPress itself has a number of features that can represent the attributes that exist in the conventional class into the online classroom [8].

WordPress has a main dashboard interface that is quite easy to understand. On the left side, there is a main menu for post management, pages, media, and comments. More clearly can be seen in Fig. 2.

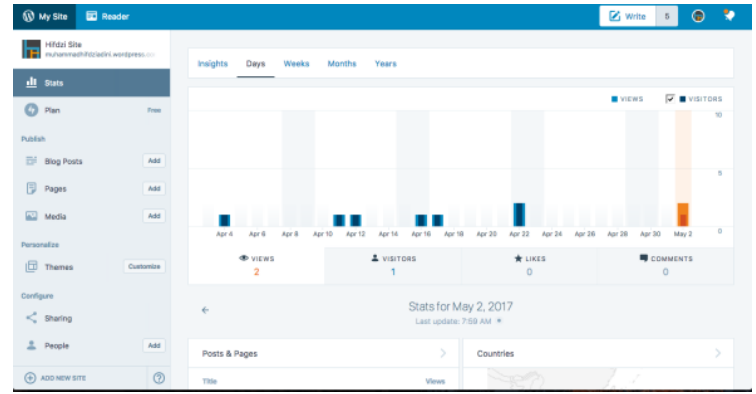

Fig 2. The main WordPress dashboard view

One of the important features contained in WordPress is Post. This post allows users to publish articles either in the form of teaching materials, lecture assignments, or other important announcements. More clearly form can be seen in Fig. 3.

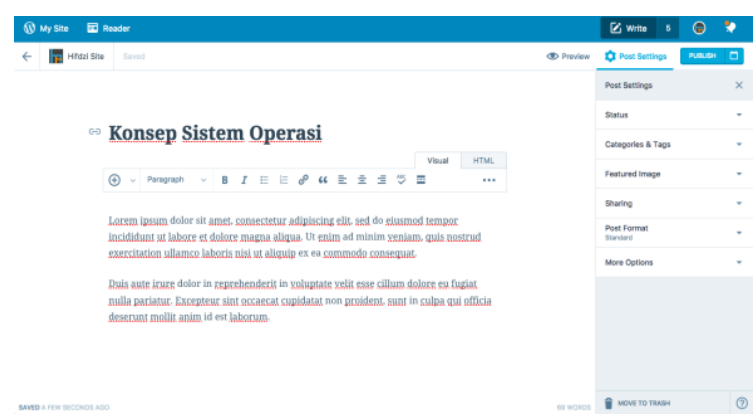

Fig. 3. Writing material and assignments

Another feature that can be used as a medium for displaying material is media management. WordPress supports media such as video, audio, and images. In addition to having independent media management, WordPress also supports embed code like links from YouTube or any other storage media to display on WordPress pages (Fig. 4)

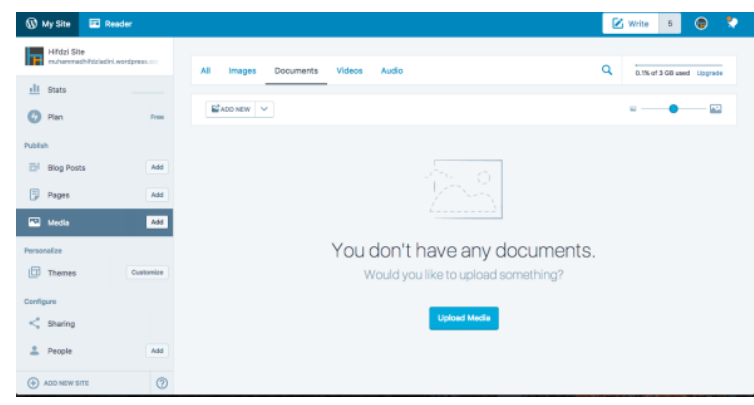

Fig 4. Media management for audio, video, and image

To represent a discussion in a conventional physical class, WordPress has a comment feature. Comments can be written by visitors (students) at the bottom of the post or page and may be 
replied by the admin (teacher) or by other visitors. More clearly can be seen in Fig. 5 .
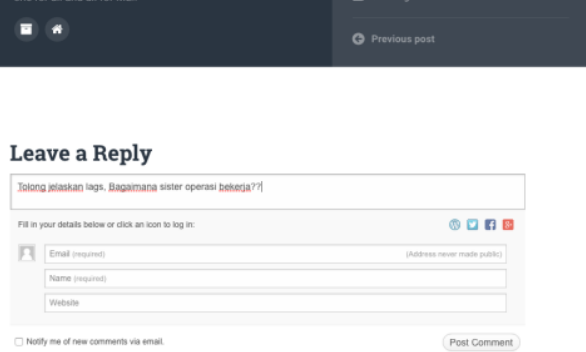

Fig. 5. Feature comment as a discussion medium

\section{CONCLUSION}

There are five major steps in the framework of blended learning implementation: (1) defining the learning objectives; (2) establishing readiness; (3) determining the blended learning model; (4) implementing the blended learning model; and (5) monitoring and evaluating.

In addition to a good framework, the selection of the right technology is also one of the factors supporting the success of the blended learning model. One of the technologies that can be used is WordPress. WordPress can be used for free, and has a number of features that can represent physical class conditions.

\section{REFERENCES}

[1] S. B. Sjukur, "Pengaruh blended learning terhadap motivasi belajar dan hasil belajar siswa di tingkat SMK," Jurnal Pendidikan Vokasi, vol. 2, no. 3, 2013.

[2] K. F. Hew and W. S. Cheung, Using Blended Learning: Evidence Based Practices, Singapore: Springer, 2014.

[3] M. B. Horn and H. Staker, "The rise of K-12 blended learning," Innosight Institute, New York, 2011.

[4] A. Ellis, "Student-centred collaborative learning via face-to-face and asynchronous online communication: what's the difference," in Proceedings 18th ASCILITE Conference, Brisbane, 2001.

[5] K. L. Foo, "Exploratory Study on Blended Learning," Unpublished master thesis Nanyang Technological University, Singapore, 2014.

[6] C. Twigg, Improving Learning and Reducing Costs: New Models for Online Learning, Philadelphia: Educause, 2003.

[7] T. C. Smith, "Fifty-one competencies for online instruction," The Journal of Educators Online, vol. 2, no. 2, pp. 1-18, 2005.

[8] S. K. Patel, V. R. Rathod and J. B. Prajapati, "Performance analysis of content management system-joomla, drupal and wordpress," International Journal of Computer Applications, vol. 21, no. 4, pp. 39-43, 2011. 